УДК $378.147: 338.48: 316.77$

DOI:

Оксана Баглай, кандидат педагогічних наук, доиент кафедра іноземних мов Національного університету “Львівська політехніка"

\title{
МІЖКУЛЬТУРНА СКЛАДОВА ПРОФЕСІЙНОЇ ПІДГОТОВКИ ФАХІВЦЯ ТУРИСТИЧНОЇ СФЕРИ
}

У статті висвітлено теоретичні аспекти професійної підготовки фахівия туристичної сфери до міжкультурної взаємодії. Зазначено, що результатом такої підготовки є фахівець, здатний до професійного самовизначення та самовдосконалення впродовж життя, готовий до спілкування з представниками інших культур, які є носіями своӥх культурних звичаїв, традицій, норм поведінки, релігійних переконань. Проаналізовано організачію навчального прочесу у закладі туристичної освіти, зокрема виокремлено блок гуманітарних дисциплін, які безпосередньо впливають на формування міжкультурної компетентності, наголошено на важливості позааудиторної та самостійної роботи студентів.

Ключові слова: професійна підготовка; фахівець туристичної сфери; міэкультурне спілкування; міжкультурна компетентність; культура спілкування.

Jim. 13.

Oksana Bahlay, Ph.D.(Pedagogy), Associate Professor of the Foreign Languages Department Lviv Polytechnic National University

\section{INTERCULTURAL COMPONENT OF A TOURISM SPECIALIST PROFESSIONAL TRAINING}

The article considers the theoretical aspects of tourism specialist professional training for multicultural interaction. The researcher analyses the concepts of "professional training", "tourism specialist professional training". The author determines that the development of tolerance, communicative culture and behaviour are the priority tasks for the effective intercultural communication. It is noted that the result of this training is a specialist capable of professional self-determination and self-improvement throughout his/her life, ready to communicate with the representatives of other cultures who are the carriers of their own, unique cultural customs, traditions, religious beliefs. The analysis of the organisation of the educational process in tourism educational institutions shows that the learning of humanitarian disciplines directly result in the formation of intercultural competence and emphasises the importance of extra-curriccular and independent work of students, practical future specialists' training abroad for acquiring practical communivative skills due to the communicative interaction with the foreigners. It is revealed that the culture of professional communication of a future tourism sphere specialist is of paramount importance in his/her becoming a subject of the intercultural dialogue. Intercultural competence is defined as the presence of knowledge, skills and abilities obtained in the process of professional training for establishing personal relationships between people or groups of people who are the representatives of different cultures for the exchange of information, values, norms of behaviour able to feel the peculiarities of dialogical relations. It is noted that intercultural competence contributes to the equal and tolerant coexistence of peoples on the principles of equality and dignity, and productive cooperation both at the social and economic levels. The recommendations for further research indicate the need for the improvement of the skills of scientific and pedagogical workers in the context of intercultural cooperation.

Keywords: professional training; tourism specialist; intercultural communication; intercultural competence; communicative culture.

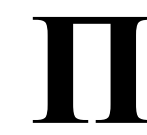

остановка проблеми. Сьогодні в гуманітарній сфері особливого звучання набуває ціннісне освоєння світу, яке передбачає, передусім, взаємоповагу один до одного, культуру спілкування, вияв толерантності. XXI століття розглядається як переломний етап у зміні ставлення до природи, людини, конкуренції в політиці та економіці, орієнтація його на людино-орієнтовану модель. Зростає значення етики спілкування, що передбачає посилену увагу до формування комунікативної культури. Простежується ланцюжок аксіологічних тверджень, на основі яких досягається усталеність суспільного життя: цивілізація, гуманізм, цінність, загальнолюдські цінності, культура спілкування тощо, зміст яких конкретизується із зміною історичних епох. У цьому аспекті провідна роль належить туристичним комунікаціям, здатним організувати щире, добровільне спілкування. Щоб результативність спілкування була продуктивною, потрібна власна зацікавленість у цьому, прикладання вольових зусиль, вміння домовлятися, налаштовуватися на доброзичливі відносини. 
Враховуючи той факт, що сьогодні планета поділена на різні регіони, які належать групам країн або поліетнічній країні, туристи беруть активну участь у комунікації з представниками різних етнічних об'єднань, на території яких розташовані рекреаційні зони і туристичні об'єкти. Тому при аналізі структури культури соціальної групи та розвитку іiі динаміки необхідно враховувати постійне перебування на території корінних жителів значної кількості представників інших культур, в результаті чого має місце ефект туристичної крос-культурної міжрегіональної комунікації.

Беручи до уваги вищесказане, можна зазначити, що комунікативна компетентність працівників туристичної сфери для інтенсивної взаємодії та комунікації з представниками різних соціумів залежить від якості їх підготовки до міжкультурного спілкування, насамперед, рівня володіння іноземною мовою та знання культурних відмінностей різних категорій туристів, які $\epsilon$ представниками культури країни, з якої вони походять.

Таким чином, сьогоднішній ринок праці у сфері туризму ставить завдання перед закладами туристичної освіти підготувати компетентного фахівця зі знаннями про міжкультурне спілкування та навичками їх застосування у професійній діяльності $з$ метою задоволення потреб туристів.

Аналіз теоретичних джерел 3 проблеми професійної підготовки фахівців показав, що питанням професійної підготовки займалися С. Батишев, Л. Костельна, О. Семеног; професійної підготовки фахівців туристичної сфери - Л. Сакун, В. Федорченко, Н. Фоменко; міжкультурне спілкування упрофесійній підготовці фахівців туристичної сфери вивчали Н. Жорняк, T. Колбіна; комунікативну компетентність фахівців туристичної сфери досліджували С. Александрова, І. Писаревський, Н. Якса та ін.

Таким чином, міжкультурна складова професійної підготовки фахівців туристичної сфери залишається актуальною проблемою й, у зв'язку 3 постійним збільшенням туристичних потоків та вимог у сфері надання туристичних послуг, потребує подальшого опрацювання.

Метою статті $\epsilon$ обгрунтування теоретичних аспектів міжкультурної складової професійної підготовки фахівців туристичної сфери.

Виклад основного матеріалу дослідження. Перш за все розглянемо поняття "професійна підготовка". Відповідно до закону України "Про вищу освіту" поняття "професійна підготовка" розглядається, як здобуття кваліфікації за відповідним напрямом підготовки або спеціальністю [6]. Науковець С. Батишев визначає це поняття як “сукупність спеціальних знань, умінь і навичок, якостей, трудового досвіду та норм поведінки, які забезпечують можливість успішної праці за обраною професією; процес повідомлення тим, хто навчається, відповідних знань, умінь і засобів діяльності" [2, 115]. О. Семеног вважає, що професійна підготовка має чітко визначену систему цілей, тому її процес спрямований на їх досягнення. Оскільки цілей $є$ багато, то підготовку можна розглядати як систему зі складною структурою, якій властиві цілісність, гнучкість, динамізм, ієрархічність. Розвиток системи передбачає її відкритість до зовнішніх впливів та здатність реагувати на них через оновлення, зміни, самовдосконалення, генерацію нових ідей, творче освоювання досвіду інших систем [9].

Отже, можна зробити висновок, що, незважаючи на використання різних підходів до трактування цього поняття, практично всі визнають за цією підготовкою в тій чи іншій мірі властивості системного об'єкта. Також автори виділяють ступеневу структуру професійної

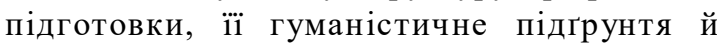
необхідність реалізації впродовж життя.

Досліджуючи теоретико-методологічні засади професійної підготовки фахівця туристичної сфери в сучасних умовах праці, В. Лозовецька зазначає, що модернізація професійної освіти в туризмі має, насамперед, передбачати: створення відповідних психолого-педагогічних умов щодо усвідомлення студентами особливостей майбутньої професійної діяльності; акцентування уваги на розвитку особистісних якостей, необхідних для успішного оволодіння майбутньою професією; розвиток професійно-важливих якостей; формування індивідуальних освітніх траєкторій у професійній підготовці і перепідготовці кадрового персоналу $[4,32]$.

На думку М. Гункевича професійна підготовка персоналу для сфери туризму включає пізнавальний, функціональний, діяльнісний та особистісний компоненти. В основі пізнавального компоненту лежить зміст професійної підготовки майбутнього фахівця, функціональний та компоненти передбачають компетентне виконання професійних функцій та здійснення різних видів діяльності на місці праці, а також готовність до здійснення професійної взаємодії зі споживачами туристичних послуг, у той час як особистісний компонент містить вміння та якості майбутнього фахівця, його професійну культуру, навички міжособистісного спілкування в контексті діалогу культур [3]. 
О. Самохвал, здійснюючи аналіз професійної підготовки фахівців туристичної сфери наголошує на тому, такі фахівці повинні бути готовими до здійснення комунікативної взаємодії зі споживачами туристичних послуг, вирішення конфліктних ситуацій задля підвищення якості надання туристичних послуг, розроблення екскурсійних та туристичних маршрутів, ведення калькуляції [8]. Кінцевим результатом професійної освіти в туризмі є фахівець, “здатний до професійного самовизначення, професійної самоактуалізації та самореалізації упродовж життя, зорієнтований до постійного спілкування 3 туристами різних культурних традицій, релігійних переконань, психічного складу” [11].

Отже, професійна підготовка фахівця туристичної сфери повинна бути орієнтована на досягнення високого рівня освіченості майбутнього фахівця, його професійну ефективність, гнучкість, здатність розвивати себе як особистість, самореалізуватися та самовдосконалюватися, оволодівати тими професійно важливими якостями, які необхідні фахівцю туристичної сфери для життя та професійної діяльності у полікультурному суспільстві.

Здатність фахівця туристичної сфери вести комунікативну взаємодію 3 споживачами туристичних послуг наголошує на необхідності його підготовки до міжкультурного спілкування, адже професійна діяльність у закладах сфери гостинності передбачає постійну взаємодію працівника $з$ представниками інших культур, участь у ділових переговорах, презентаціях, конференціях тощо. Процес міжкультурного спілкування передбачає не лише знання іноземної мови для порозуміння зі співрозмовником. У цьому контексті варто наголосити на важливості володіння фахівцем знаннями про культурні норми, цінності, правила поведінки, історію, звичаї та традиції для успішного ведення міжкультурного діалогу [1].

Культура професійного спілкування майбугнього фахівця туристичної сфери $є$ провідною в його становленні як суб'єкта міжкультурної взаємодії. У спілкуванні формуються стосунки між двома сторонами, незалежно від фізичного чи нефізичного характеру взаємодії. У будь-якому разі в процесі спілкування треба вміти слухати, відчувати стан партнера, виявляти повагу, адекватно вибирати способи й засоби комунікації. Рівень професійної майстерності фахівців багатьох професій, зокрема туристичних, залежить від знання технологій спілкування та вміння їх застосовувати. У процесі міжкультурної комунікації відбувається вербальне або невербальне спілкування людей, які користуються різними мовами, належать до різних лінгвокультурних спільнот, мають різний рівень сформованості комунікативної компетенції. Це вимагає підготовленості суб' єктів спілкування до застосування таких мовних кодів, які правильно передадуть смисл інформації тому, хто живе в іншій культурі. У зв'язкуз цим під час спілкування часто складаються ситуації так, що партнер відчуває незручність із-за власного низького рівня проінформованості про особливості міжкультурної комунікації. Щоб уникнути таких ситуацій, необхідно користуватися відповідними тактиками й стратегіями спілкування. Якщо розглядати специфіку міжкультурної комунікації у контексті лінгвістичних досліджень, то вона має міждисциплінарну природу і тісно пов'язана 3 етнолінгвістикою, лінгвокультурологією і комунікативною лінгвістикою. Теорія міжкультурної комунікації вивчає основи взаємодії носіїв різних ідіоетнічних культур із врахуванням відмінностей у вживанні культурно-специфічних понять, які виникають внаслідок особливостей психологічного сприйняття, соціального і когнітивного досвіду $[10,9]$.

Зосередимо увагу на визначенні сутності поняття “міжкультурне спілкування" та вмінні його реалізовувати на практиці майбутніми фахівцями туристичної сфери. Міжкультурне спілкування можна визначити як особистісний зв'язок між людьми чи групами людей, як $є$ представниками різних культур, здатних відчувати особливості діалогічних відносин, враховуючи спільні інтереси та цінності. Результативність такого спілкування у туристичній сфері залежить від внутрішньої мотиваційної налаштованості його суб'єктів та їх готовності до усунення комунікативних суперечностей.

Міжкультурна складова професійної підготовки фахівця туристичної сфери передбачає необхідність підготовки майбутніх фахівців до життя та діяльності в полікультурному просторі XXI ст., де через постійне зростання кількості туристичних потоків, поширення міжнародних освітніх програм та проектів виникає потреба у налагодженні контактів $з$ людьми інших культур.

Процес професійної підготовки фахівців туристичної сфери передбачає вивчення дисциплін відповідно до навчального плану підготовки. Візьмемо навчальний план підготовки бакалавра галузі знань 24 “Сфера обслуговування”, спеціальності 242 “Туризм”. Цикли соціальногуманітарної підготовки та фундаментальної, природничо-наукової та загальноекономічної підготовки включають такі дисципліни: Історія і 


\section{МІЖКУЛЬТУРНА СКЛАДОВА ПРОФЕСІЙНОӤ ПІДГОТОВКИ ФАХІВЦЯ ТУРИСТИЧНОЇ СФЕРИ}

культура України, Українська мова (за професійним спрямуванням), Географія туризму, Туристичне країнознавство; цикл професійної та практичної підготовки - Іноземна мова (за професійним спрямуванням), Друга іноземна мова (за професійним спрямуванням), Організація екскурсійної діяльності, Організація дозвілля. До варіативної навчального плану включені наступні дисципліни: Світова культура і мистецтво, Туристичне краєзнавство, Діловий етикет, тощо. Компетенції, які формуються у студентів у процесі вивчення цих дисциплін, для прикладу при вивченні іноземних мов, відповідно до програм $є$ : дискурсивна (вміння керувати своїм мовленням), соціолінгвістична (вміння враховувати національну приналежність та соціальні особливості мовця), соціокультурна (вміння успішної соціальної взаємодії, вирішення спільних соціальних проектів), (інформаційна: вміння застосовувати інформаційно-комунікативні технології у професійній діяльності та повсякденномужитті), професійно-комунікативна (вміння здійснювати професійне спілкування, вибираючи відповідні вербальні та невербальні засоби). Отже, можна стверджувати, що саме дисципліни гуманітарного блоку, завдяки їх якісному вивченню, лежать в основі ефективної підготовки до міжкультурного спілкування.

Міжкультурне спілкування базується на власному культурному досвіді студентів, на вже наявних у них знаннях іншомовної культури, розширенні кругозору студентів, одночасно розвиваючи його морально-особистісні основи, а також передбачає пізнання й розуміння іншої культури.

У працях М. Розквітальської зазначено, що підготовка майбутнього фахівця туристичної сфери до міжкультурного спілкування неможлива без інформування студентів про те, як міжкультурні відмінності безпосередньо впливають на результат спілкування. Знання про культурне підгрунтя та комунікацію можуть суттєво підвищити рівень відчуття та сприйняття під час взаємодії з представниками іншої культури, сприяти розвитку поваги та толерантності між суб'єктами спілкування [13]. Результат міжкультурного спілкування залежить від здатності та готовності учасників цього процесу розвивати, налагоджувати та покращувати відносини з представниками інших культур [12].

Компетентнісний підхід до професійної підготовки фахівця туристичної сфери орієнтує на нові цілі в туристичній освіті. Згідно з тлумачними словниками, компетентність (лат. competens “відповідний”, “здатний”) - психосоціальна якість, що означає силу і впевненість, які грунтуються на відчутті власної успішності та корисності, що дає людині усвідомлення своєї спроможності ефективно взаємодіяти з оточенням [7, 188 - 189]. За словами В. Манакіна, “завданням міжкультурної комунікації $€$ формування міжкультурної компетентності, необхідних знань про різні народи та культури з метою уникнення міжетнічних $\mathrm{i}$ міжкультурних конфліктів та встановлення комфортних умов спілкування в різних сферах та життєвих ситуаціях" $[5,10]$.

На основі вищесказаного, виокремимо структурні компоненти міжкультурної компетентності: емоційний, який характеризується наявністю емпатії та толерантності для ефективної міжкультурної взаємодії; когнітивний (знання основних аспектів рідної культури та культури країни, мова якої вивчається, а також знання про культуру спілкування), міжкультурна проінформованість (усвідомлення необхідності знань про міжкультурні відмінності з метою запобігання виникнення міжкультурних конфліктів та бажання їх усувати у випадку ї виникнення; бути відкритим до діалогу через призму власних культурних цінностей та норм поведінки); діяльнісний компонент містить вміння комуніканта застосовувати набуті знання у процесі міжкультурного діалогу, вирішення конфліктних ситуацій в умовах професійної діяльності.

Таким чином, варто наголосити, що саме міжкультурна компетентність сприяє рівноправному й толерантному співіснуванню народів на засадах рівності та гідності й результативній співпраці як на соціальному, так і на економічному рівнях.

Попри вивчення дисциплін відповідно до навчального плану, на формування міжкультурної компетентності ефективно впливає залучення студентів до різних видів позааудиторної діяльності, наприклад конкурсів, фестивалів, пов'язаних з звичаями різних країн світу. Організація самостійної роботи студентів, для прикладу, підготовка доповідей, рефератів, проектів про культурну приналежність різних народів, участь у конференціях, присвячених організації туристичної діяльності, діловому етикету тощо, має велике значення для цього процесу. Беззаперечним $є$ практичний досвід підготовки майбутніх фахівців. Доцільним є залучення студентів до стажування за кордоном у закладах туристичної сфери не лише для здобуття практичних навичок майбутньої професійної діяльності, а й для набуття знань про цінності, традиції, норми поведінки в іншій країні та набуття досвіду спілкування шляхом 
безпосередньої взаємодії з представниками інших культур.

Висновки та перспективи подальших розвідок. Отже, ефективне виконання професійних обов'язків фахівцем потребує системи знань, умінь і навичок міжкультурного спілкування. Міжкультурна компетентність як передумова результативної професійної діяльності у сфері туризму залежить від якості підготовки майбутнього фахівця у закладі професійної туристичної освіти, організації навчального процесу, метою якого має бути фахівець, готовий до досягнення комунікативних цілей, зокрема уникнення конфліктних ситуацій, подолання бар'єрів спілкування 3 представниками інших культур під час міжкультурної взаємодії завдяки таким особистісним рисам як емпатія, толерантність, культура спілкування, міжкультурна проінформованість. Отже, важливість міжкультурна складова професійної підготовки фахівця туристичної сфери $\epsilon$ беззаперечною.

Оскільки, процес формування міжкультурної компетентності не завершується процесом навчання у закладі туристичної освіти, а продовжується та вдосконалюється у процесі професійної діяльності впродовж життя, подальшого вдосконалення потребує організація кадрового забезпечення галузі, зокрема розробка методичних рекомендацій щодо підвищення рівня міжкультурної компетентності науковопедагогічних працівників закладів туристичної освіти.

\section{ЛІТЕРАТУРА}

1. Александрова С. А. Формування міжкультурної компетентності студентів туристських спеціальностей. Вісник Луганського національного Університету ім. Тараса Шевченка. Серія: Педагогічні науки. Частина I. 2011. № 14 (225). С. 6 - 10.

2. Батышев С. Я. Профессиональная педагогика. Москва, 1997. 512 с.

3. Гункевич М. Б. Вісник Луганського національного Університету ім. Тараса Шевченка. Серія: Педагогічні науки. Частина III. 2013. № 18 (277). С. $34-39$.

4. Лозовецька В. Т. Теоретичні і практичні засади застосування компетентнісно-діяльнісного підходу у підготовці фахівця туризму. Туристична освіта в Україні: проблеми і перспективи: зб. наук. праць. Київ, 2007. С. 28-35.

5. Манакін В.М. Мова і міжкультурна комунікація: Навч. посібник для університетів. Київ: Академія, Серія “Альма-матер”, 2012. 285 с.

6. Про вищу освіту: Закон України від 01.07.2014, №1556-VII ULR:http://sfs.gov.ua/ diyalnist-/zakonodavstvo-pro-diyalnis/zakoni-ukraini/ 65715.html.

7. Психологічний тлумачний словник найсучасніших термінів : близько 3000 слів / ред. В. Б. Шапар. Харків: Прапор, 2009. 672 с.

8. Самохвал О.О. Теоретичні основи змісту професійної підготовки майбутніх фахівців туристичної галузі у ВНЗ України. "Young Scientist”. № 11 (38). 2016. С. 497-501.

9. Семеног О. М. Система професійної підготовки майбутніх учителів української мови i літератури (в умовах педагогічного університету): дис. ... доктора пед. наук: 13.00.04. Київ, 2006. $560 \mathrm{c.}$

10. Словник термінів міжкультурної комунікації / уклад. Ф. С. Бацевич. Київ: Довіра, 2007. 208 с.

11. Фокін С. П., Гайова О. М. Педагогічні аспекти підготовки фахівців туризму у вищих навчальних закладах України. Науковий вісник Інституту міжнародних відносин НАУ. Серія: економіка, право, політологія, туризм. 2012. № 2 (2). С. 5.

12. Чаграк Н. І., Гритчук Г. В. Міжкультурна комунікація як компонент професійної компетентності фахівця сфери туризму. Вісник Луганського національного університету. Луганськ, 2010. №16. С. 83-89.

13. Rozkwitalska, M., Jukasz Suikowski, Slawomir Magala (Eds.). (2017). Cognition of the Multicultural Work Environment in Multinational Corporations and Intercultural Interaction Outcomes. Intercultural Interactions in the Multicultural Workplace: Traditional and Positive Organizational Scholarship, pp.37-51. URL: https://doi.org/10.1007/ 978-3-319-39771-9 3

\section{REFERENCES}

1. Aleksandrova, S. A. (2011). Formuvannia mizhkulturnoi kompetentnosti studentiv turystskykh spetsialnostei [Future tourism specialists' intercultural competence formation]. Journal of Ivan Franko Luhansk National University. Series: pedagogical sciences. Part 1, № 14 (225). pp. 6-10. [in Ukrainian].

2. Batyshev, S. Ya. (1997). Professionalnaia pedagogika [Professional pedagogy]. Moskov, 512 p.[in Russian].

3. Hunkevych, M. B. (2013). Suchasni tendentsii protsesiv pidhotovky fakhivtsiv halyzi turyzmu $v$ Ukraini [Modern tendencies of tourism sphere specialists training in Ukraine]. Luhansk, No. 18 (277), pp. 34 - 39. [in Ukrainian].

4. Lozovetska, V. T. (2007). Teoretychni i praktuchni zastosuvannia kompetentnisno-diialnisnoho pidkhodu u pidhotovtsi fakhivtsia turyzmu [Theoretical 
and practical principles of a competence and operational approach application in a tourism specialist training]. Tourism education in Ukraine: a collection of scientific works. Kyiv, pp. 28-35.[in Ukrainian].

5. Manakin, V. M. (2012). Mova i mizhkulturna komunikatsiia [Language and intercultural communication]. A handbook for university students. Kyiv, Series "Alma-mater", 285p. [in Ukrainian].

6. Zakon pro Vyshchu osvitu [On higher Education]. Law of Ukraine of 01.07.2014, №1556VII. Available at: http://sfs.gov.ua/diyalnist-/ zakonodavstvo-pro-diyalnis/zakoni-ukraini/ 65715.html.[in Ukrainian].

7. Shapar,V. B. (Ed.). (2009). Psykholohichnyi tlumachnyi slovnyk of naisuchasnishyh terminiv: blyzko 3000 sliv [Psychological dictionary of the newest terms: nearly 3000 words]. Kharkiv, Prapor, 672 p. [in Ukrainian].

8. Samohval, O. O. (2016). Teoretychni osnovy zmistu profesiinoi pidhotovky maibutnih fahivtsiv turychnoi haluzi u VNZ Ukrainy [Theoretical fundamentals of the content of future tourism sphere specialists in higher educational establishments in Ukraine]. Young Scientist, No. 11 (38), pp. 497-501. [in Ukrainian].

9. Semenoh, O. M. (2006). Systema profesiinoi pidhotovky maibutnih uchyteliv ukrainskoi movy i literaturu (v umovah pedahohichnoho universytetu)
[System of future Ukrainian language and literature teachers training (in a pedagogical university)]. Kyiv, 560 p. [in Ukrainian].

10. Batsevych, F. S. (2007). Slovnyk terminiv mizhkulturnoi komunikatsii [Dictionary of intercultural communication terms]. Kyiv, Dovira, 208 p. [in Ukrainian].

11. Fokin, S. P. \& Haiova, O. M. (2012). Pedahohichni aspekty pidhotovky fahivtsiv turyzmu y vushchyh navchalnyh zakladah Ukrainy [Pedagogical aspects of tourism specialists training in higher educational establishments of Ukraine]. Scientific journal of International Relations Institute of National Academy of Sciences. Series: economics, law, politology, tourism. No. 2 (2). p. 5. [in Ukrainian].

12. Chahrak, N. I. \& Hrytchuk, N. I. (2010). Mizhkulturna komynikatsiia yak komponent profesiinoi kompetentnosti fahivtsia sfery tyryzmu [Intercultural communication as a component of tourism sphere specialists' professional competence]. Journal of Luhansk National University. Luhansk, No.16, pp. 83-89. [in Ukrainian].

13. Rozkwitalska, M. (2017). Cognition of the Multicultural Work Environment in Multinational Corporations and Intercultural Interaction Outcomes. In M. Rozkwitalska, Jukasz Suikowski, Slawomir Magala (Eds.), Intercultural Interactions in the Multicultural Workplace: Traditional and Positive Organizational Scholarship, 37-51. Available at: $\underline{\text { https:/ }}$ /doi.org/10.1007/978-3-319-39771-9 3 [in English].

Стаття надійшла до редакції 04.02.2019

\section{

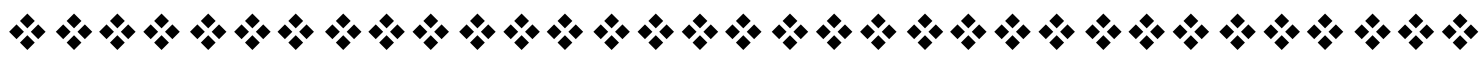

"Ну що б, здавалося, слова... Слова та голос - більш нічого. А серие б"ється -ожива, яК ïх nочує!"

TТарас Шевченко

український поет, писъменник

“Фобрі слова залишають в душах людей преқрасний слід. Вони пом'яқиують, втішають $і$ зиіляють серие того, хто їх чує”.

Блез Тасқаль

франиузький білособ

“Справа не стільки в тому, цо ви говорите, сқільки в тому, якговорите”.

Квінтіліан

римський педагог

\section{$\% * 4 * 4 \% * 4 \%$

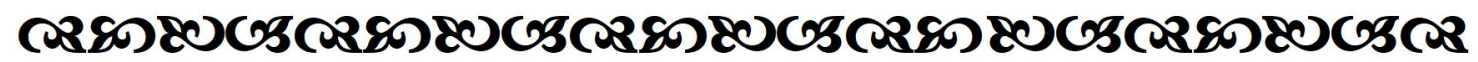

